\title{
ANALISIS DESKRIPTIF PROFIL KEAGAMAAN MAHASISWA MUSLIM TINGKAT 1 JURUSAN MATEMATIKA FMIPA UNIVERSITAS ANDALAS ANGKATAN 2013
}

\author{
SENO PRATAMA, HAZMIRA YOZZA, IZZATI RAHMI HG \\ Program Studi Matematika, \\ Fakultas Matematika dan Ilmu Pengetahuan Alam, Universitas Andalas, \\ Kampus UNAND Limau Manis Padang, Indonesia, \\ senopratama09@yahoo.com
}

\begin{abstract}
Abstrak. Pada penelitian ini dikaji profil keagamaan mahasiswa muslim tingkat 1 angkatan 2013 Jurusan Matematika FMIPA Universitas Andalas dengan menggunakan analisis statistika. Analisis yang digunakan adalah analisis deskriptif dengan menggunakan tabel dan diagram, serta analisis gerombol. Pengambilan data dilakukan dengan menggunakan kuisioner yang telah valid dan reliabel. Diperoleh kesimpulan bahwa profil keagamaan mahasiswa tersebut belum begitu baik karena masih adanya mahasiswa yang tidak mengerjakan ibadah wajib secara rutin. Selain itu, mahasiswa juga dibagi menjadi tiga kelompok berdasarkan tingkat perilaku keagamaannya (relatif baik, cukup baik, dan kurang baik), sehingga diperoleh bahwa distribusi mahasiswa terbanyak terletak pada kelompok yang relatif cukup baik. Dimana pada kelompok tersebut mahasiswa hanya sering mengerjakan shalat wajib, berzikir/berdoa, berpuasa, dan muamalah, sedangkan untuk shalat sunnah dan menambah ilmu agama melalui Alquran/Hadis ataupun media informasi sangat jarang dilakukan.
\end{abstract}

Kata Kunci: Analisis deskriptif, uji validitas, uji reliabilitas, analisis gerombol, ANOVA

\section{Pendahuluan}

Mahasiswa merupakan suatu contoh dari populasi manusia yang memiliki pe-ranan penting dalam perubahan kehidupan sosial dan keagamaan di masyarakat. Perguruan tinggi, selain sebagai wadah pembentukan kaum intelektual, juga merupakan pusat tumbuhnya aktivitas keagamaan. Perguruan tinggi memberikan wadah bina keagamaan kepada mahasiswa baru yang bertujuan untuk membentuk karakter mahasiswa yang lebih baik dengan meningkatkan IMTAQ dan perilaku mahasiswa itu sendiri. Pembinaan tersebut akan lebih mudah jika mengetahui karakter mahasiswa yang akan dibina. Oleh sebab itu, seluruh masyarakat perguruan tinggi perlu mengenal dan mengetahui lebih baik profil dari mahasiswa baru tersebut.

Pada paper ini akan dikaji profil keagamaan di kalangan mahasiswa baru dari keberagaman perilaku keagamaan mereka sehari-hari dengan menggunakan analisis statistika. Analisis yang digunakan adalah analisis deskriptif dan analisis gerombol. 


\section{Tinjauan Pustaka}

\subsection{Teknik Pengumpulan Data}

Salah satu alat yang dapat digunakan untuk mengumpulkan data adalah kuisioner. Tujuan utama pembuatan kuisioner adalah memperoleh informasi yang relevan sesuai tujuan survei atau sensus dengan validitas dan reliabilitas setinggi mungkin [5]. Misal suatu peubah pada kuisioner diukur melalui $k$ pernyataan. Validitas dari pernyataan ke- $j, j=1,2, \cdots, k$ diukur dengan membandingkan $r_{h i t}$ dengan $r_{k r i t i k}$, dimana $r_{h i t}$ merupakan korelasi dari pernyataan ke- $j$ terhadap peubah yang mewakilinya, sehingga diperoleh rumus $r_{h i t}$ sebagai berikut:

$$
r_{h i t j}=\frac{n \sum_{i=1}^{n} x_{i j} y_{i}-\left(\sum_{i=1}^{n} x_{i j}\right)\left(\sum_{i=1}^{n} y_{i}\right)}{\sqrt{\left[n \sum_{i=1}^{n} x_{i j}^{2}-\left(\sum_{i=1}^{n} x_{i j}\right)^{2}\right]} \sqrt{\left[n \sum_{i=1}^{n} y_{i}^{2}-\left(\sum_{i=1}^{n} y_{i}\right)^{2}\right]}},
$$

sedangkan $r_{k r i t i k}$ adalah nilai kritis pengujian pada taraf nyata $\alpha$ tertentu dan $n$ jumlah sampel. Pernyataan disimpulkan valid apabila $r_{h i t} \geq r_{k r i t i k}$.

Salah satu koefisien keterandalan kuisioner adalah dengan koefisien kekonsistenan internal [3]. Metode yang biasa digunakan untuk mengukur koefisien tersebut adalah metode Cronbach Alpha $\left(C_{\alpha}\right)$ yang didefinisikan sebagai berikut:

$$
C_{\alpha}=\left(\frac{k}{k-1}\right)\left(1-\frac{\sum s_{i}^{2}}{s_{t}^{2}}\right)
$$

Pedoman umum yang biasa digunakan untuk menilai keterandalan kuisioner dengan menggunakan nilai $C_{\alpha}$ yaitu [6]:

Tabel 2.1.1 Tabel Pengukuran Nilai Cronbach Alpha

\begin{tabular}{|c|c|}
\hline Nilai Cronbach Alpha & Interpretasi keterandalan kuisioner \\
\hline $0,8 \leq C_{\alpha}<1$ & Sangat tinggi \\
\hline $0,6 \leq C_{\alpha}<0,8$ & Tinggi \\
\hline $0,4 \leq C_{\alpha}<0,6$ & Cukup \\
\hline $0,2 \leq C_{\alpha}<0,4$ & Rendah \\
\hline $0 \leq C_{\alpha}<0,2$ & Tidak dapat diandalkan \\
\hline
\end{tabular}

\subsection{Analisis Deskriptif}

Statistika deskriptif merupakan bidang ilmu statistika yang mempelajari caracara pengumpulan, penyusunan, dan penyajian data suatu penelitian [7]. Penyajian dalam bentuk gambar, grafik, atau diagram dapat lebih menjelaskan hasil data secara visual. Diagram batang adalah gambaran mengenai suatu distribusi frekuensi, dimana untuk setiap kelas dinyatakan dalam skala horizontal (datar) dan frekuensinya dalam skala vertikal (tegak), atau sebaliknya.

Analisis deskriptif merupakan analisis yang paling mendasar untuk memberikan gambaran umum dari informasi data. Analisis deskriptif ini meliputi beberapa hal, yaitu distribusi frekuensi, pengukuran tendensi sentral, dan pengukuran variabilitas, dan lain-lain. 
40 Seno Pratama et al.

\subsection{Analisis Gerombol}

Analisis gerombol merupakan analisis statistik yang digunakan untuk mengelompokkan $n$ objek ke dalam $K$ buah kelompok, dengan setiap objek dalam kelompok memiliki keragaman yang kecil dibandingkan objek kelompok lainnya. Semakin besar kemiripan (homogenitas) dalam kelompok dan semakin besar perbedaan (heterogenitas) antar kelompok maka penggerombolan akan semakin baik atau lebih berbeda [1].

Analisis gerombol terdiri dari beberapa proses dasar, yakni:

1. Merumuskan masalah.

Perumusan masalah dilakukan dengan memilihan variabel-variabel yang akan dipergunakan untuk penggerombolan.

2. Memilih ukuran jarak atau similaritas.

Jarak Euclidian adalah jarak yang paling umum dan paling sering digunakan dalam analisis gerombol. Jarak Euclidian antara objek ke- $i$ dengan centroid (pusat) gerombol ke- $k$ dari $r$ peubah didefinisikan:

$$
d\left(x_{i}, \mu_{k}\right)=\left[\sum_{p=1}^{r}\left(x_{i p}-\mu_{k p}\right)^{2}\right]^{\frac{1}{2}} .
$$

3. Melakukan proses standarisasi data jika diperlukan.

Jika data memang mempunyai satuan yang berbeda, pada data harus dilakukan proses standarisasi dengan mengubah data yang ada ke Z-Score.

4. Memilih suatu prosedur penggerombolan.

Penggerombolan dapat dilakukan dengan dua metode yaitu gerombol hirarki dan gerombol non hirarki (metode K-Means Cluster). Adapun tahapan-tahapan dalam metode K-Means yaitu:

(1) Menentukan banyaknya gerombol yang dihasilkan $(K)$,

(2) Mengalokasikan masing-masing objek ke dalam gerombol yang ada,

(3) Menentukan centroid (pusat) masing-masing gerombol yang didefinisikan dengan

$$
\mu_{k}=\frac{1}{N_{k}} \sum_{q=1}^{N_{k}} x_{q}
$$

(4) Menghitung jarak antara setiap objek dengan setiap centroid.

(5) Mengevaluasi keanggotaan objek dengan memasukkan objek ke gerombol dengan jarak terkecil.

(6) Jika terbentuk gerombol baru, maka ulangi tahap (3) - - (5) sampai tidak ada lagi perpindahan objek.

5. Melakukan interpretasi terhadap gerombol yang telah terbentuk.

\subsection{Analisis Variansi}

Konsep analisis variansi didasarkan pada konsep $F$-rasio yang menyatakan besarnya pengaruh pada masing-masing variabel antar kelompok. Perhitungan $F$-rasio diilustrasikan pada tabel berikut: 
Tabel 2.4.1 : Tabel ANOVA

\begin{tabular}{|c|c|c|c|c|}
\hline $\begin{array}{c}\text { Sumber } \\
\text { Keragaman }\end{array}$ & df & $\begin{array}{l}\text { Jumlah } \\
\text { Kuadrat }\end{array}$ & $\begin{array}{l}\text { Kuadrat } \\
\text { Tengah }\end{array}$ & $\mathrm{F}$ rasio \\
\hline $\begin{array}{l}\text { Between / Antara } \\
\text { Kelompok }\end{array}$ & $k-1$ & SSB & MSB & $M S B$ \\
\hline $\begin{array}{l}\text { Within / Dalam } \\
\text { Kelompok }\end{array}$ & $n-k$ & SSW & MSW & $\overline{M S W}$ \\
\hline Total & $n-1$ & SST & & \\
\hline
\end{tabular}

dimana

$$
\begin{aligned}
S S W & =\sum_{i=1}^{k} \sum_{j=1}^{n_{i}}\left(x_{i j}-\overline{x_{i}}\right)^{2}, \\
S S T & =\sum_{i=1}^{k} \sum_{j=1}^{n_{i}}\left(x_{i j}-\overline{\bar{x}}\right)^{2}, \\
S S B & =S S T-S S W \\
M S B & =\frac{S S B}{d f_{B}}=\frac{S S B}{k-1} \\
M S B & =\frac{S S W}{d f_{W}}=\frac{S S W}{n-k} .
\end{aligned}
$$

\section{Metode Penelitian}

Tahapan-tahapan yang dilakukan dalam penelitian ini:

1 Menentukan responden, dimana responden tersebut merupakan seluruh mahasiswa baru angkatan 2013 Jurusan Matematika Universitas Andalas yang beragama Islam.

2 Pembuatan kuisioner yang dibagi menjadi dua bagian, yaitu perilaku keagamaan sehari-hari dan pandangan mahasiswa terhadap berbagai aktivitas yang sering dijumpai dalam pergaulan.

3 Penyebaran kuisioner secara langsung ke seluruh responden yang telah dikumpulkan pada waktu dan tempat tertentu.

4 Pengujian kevalidan dan keterandalan kuisioner dengan menggunakan uji validitas dan reliabilitas. Sebelumnya jawaban/data pada kuisioner diubah dari skala ordinal ke bentuk skala nominal.

5 Penyajian data dengan menggunakan analisis deskriptif berupa diagram batang.

6 Menggerombolkan mahasiswa berdasarkan tingkat perilaku agama dengan menggunakan metode $K$-Means pada analisis gerombol tak berhirarki.

\section{Hasil dan Pembahasan}

Kuisioner diberikan kepada 134 responden yang beragama Islam dengan tingkat pengembalian $92 \%$ (124 responden yang mengembalikan kuisioner). 


\subsection{Analisis Deskriptif}

\subsubsection{Perilaku Keagamaan Sehari-hari}

Dalam penelitian ini, perilaku keagamaan yang diteliti meliputi ibadah wajib, ibadah sunah, kedisiplinan dalam melakukan ibadah, muamalah, dan minat responden dalam mencari ilmu keagamaan.

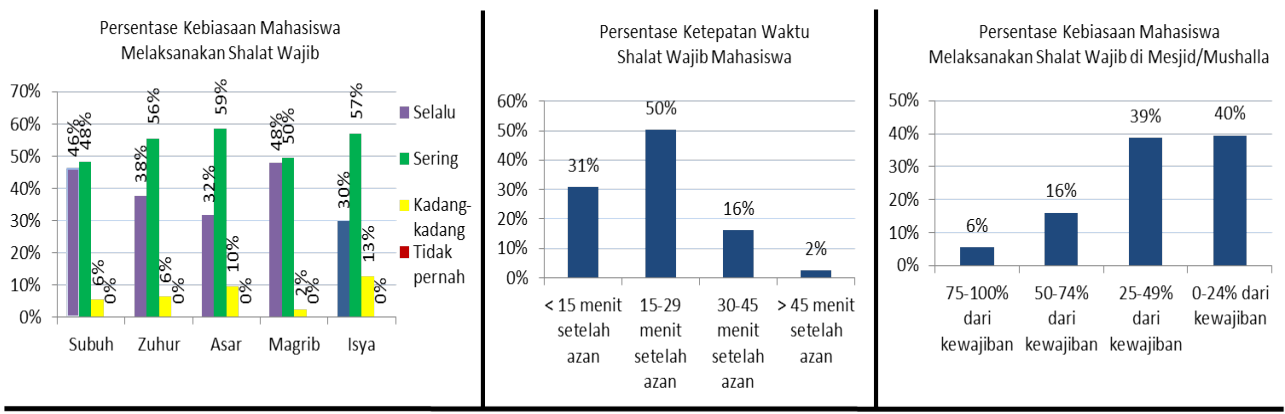

Gambar 4.1 Diagram Batang Shalat Wajib Mahasiswa

Dari Gambar 4.1 terlihat bahwa masih banyak mahasiswa yang tidak rutin dalam menjalankan ibadah shalat wajib. Tidak sampai $50 \%$ mahasiswa menjalankan ibadah shalat wajib secara rutin, bahkan sekitar 10\% mahasiswa kadang-kadang melaksanakannya. Selain itu juga banyak mahasiswa yang melalaikan waktu shalat dan tidak melaksanakannya di Mesjid ataupun Mushalla.
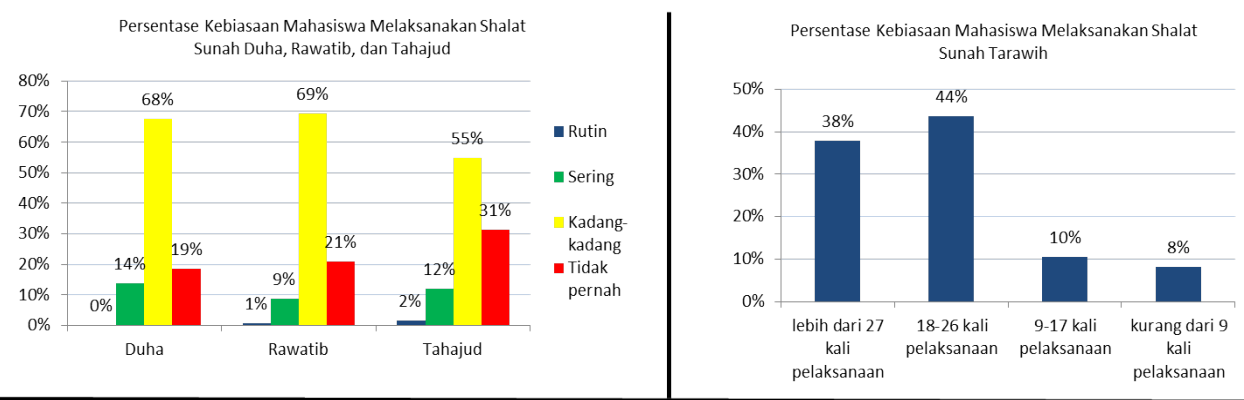

Gambar 4.2 Diagram Batang Shalat Sunnah Mahasiswa

Pada Gambar 4.2 dapat dilihat shalat sunnah yang biasa dikerjakan mahasiswa sehari-hari (shalat Duha, Rawatib dan Tahajud) serta shalat sunah yang hanya dikerjakan di bulan Ramadan (shalat Tarawih). Dari kedua jenis shalat sunah tersebut (berdasarkan waktunya), mahasiswa lebih banyak yang selalu/sering melaksanakan ibadah shalat Tarawih di bulan Ramadan. Walaupun demikian, pelaksanaan shalat tarawih ini masih perlu diperhatikan, karena tingkat mahasiswa yang jarang/tidak melaksanakan shalat tarawih hampir mencapai 20\%, mengingat ibadah ini merupakan ibadah yang istimewa dan hanya dilakukan sebulan dalam satu tahun. 

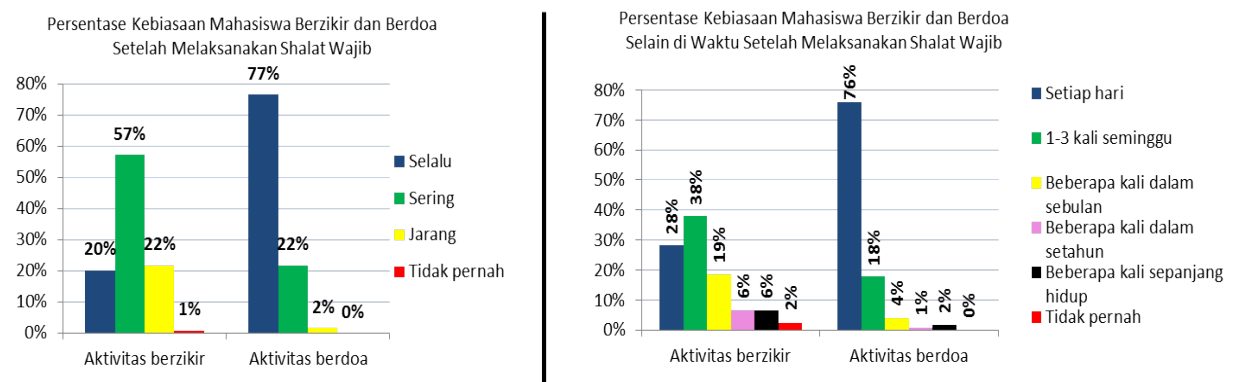

Gambar 4.3 Diagram Batang Kebiasaan Berzikir dan Berdoa Mahasiswa

Dari Gambar 4.3 dapat dilihat bahwa hanya sekitar 20\% sampai $28 \%$ mahasiswa yang rutin mengerjakan zikir setiap selesai shalat dan di luar waktu shalat setiap hari. Lain halnya dengan berdoa, cukup banyak (sekitar 76\%) mahasiswa mengerjakan rutin doa setiap selesai shalat wajib maupun di luar waktu shalat wajib setiap harinya.
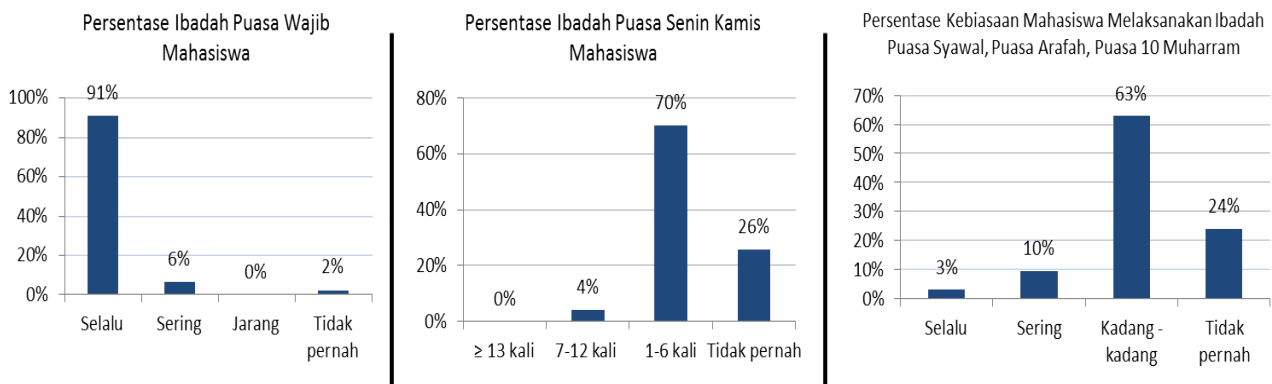

Gambar 4.4 Diagram Batang Ibadah Puasa Mahasiswa

Dari Gambar 4.4 dapat dilihat kebiasaan mahasiswa dalam melaksanakan ibadah puasa wajib maupun puasa sunah. Untuk puasa wajib masih terdapat sekitar $2 \%$ mahasiswa yang tidak pernah melaksanakannya. Sedangkan untuk puasa sunah (puasa Senin Kamis, puasa Arafah, puasa Syawal) terdapat sekitar 25\% mahasiswa yang tidak melaksanakannya.
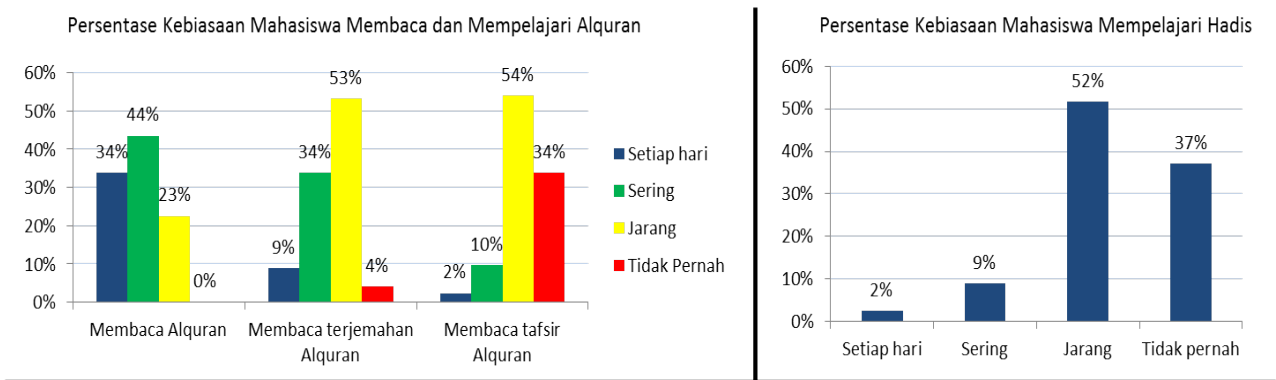

Gambar 4.5 Diagram Batang Alquran dan Hadis Mahasiswa

Gambar 4.5 dapat dilihat bahwa sebagian mahasiswa hanya membaca alquran tanpa membaca arti dan mempelajarinya, sehingga persentase mahasiswa yang selalu/sering membaca Alquran tidak berbanding lurus dengan kebiasaannya mem- 
pelajari isi Alquran tersebut. Sedangkan untuk mempelajari Hadis, banyak mahasiswa yang jarang atau tidak pernah mempelajarinya.

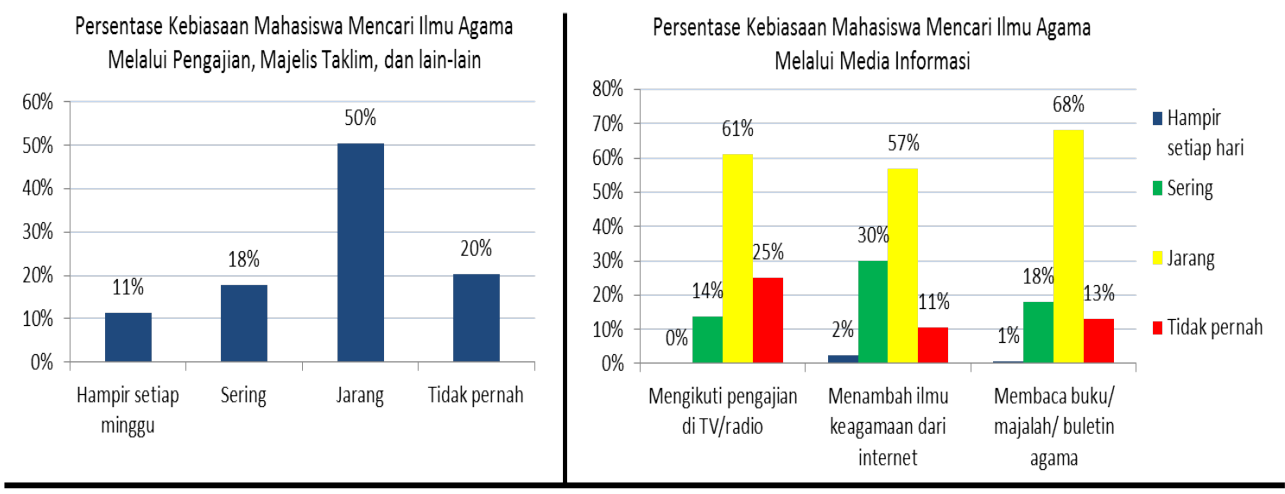

Gambar 4.6 Diagram Batang Minat Mahasiswa Mencari Ilmu Agama

Pada Gambar 4.6 dapat dilihat profil mahasiswa dalam mencari ilmu agama, baik secara langsung (mengikuti pengajian) maupun tidak langsung (melalui media informasi). Dari gambar terlihat hanya $\pm 11 \%$ mahasiswa yang mengikuti pengajian setiap minggunya. Sedangkan pencarian ilmu agama melalui media informasi, mahasiswa lebih sering mendapatkan melalui internet $( \pm 32 \%)$ dibandingkan $\mathrm{TV} /$ radio $( \pm 14 \%)$ atau buku/majalah agama $( \pm 19 \%)$.

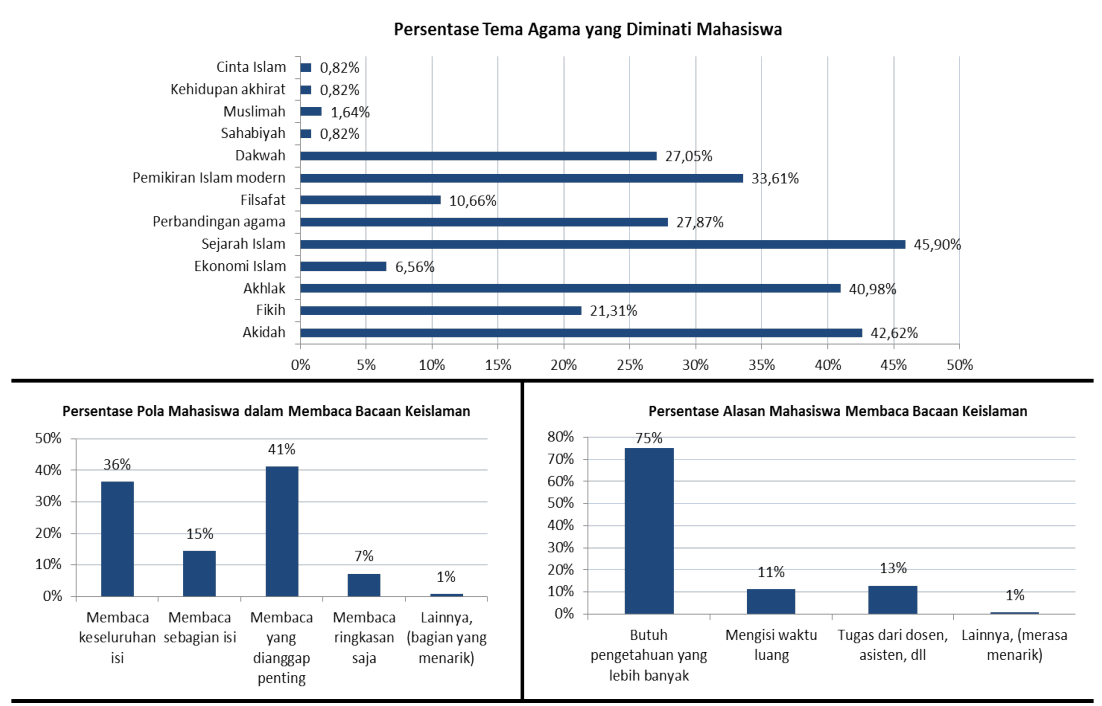

Gambar 4.7 Diagram Batang Mengenai Bacaan Agama Mahasiswa

Dari Gambar 4.7 memperlihatkan bahwa bacaan keislaman yang paling diminati oleh mahasiswa yaitu sejarah Islam. Sebesar $75 \%$ mahasiswa membaca buku/bacaan keislaman karena ingin mengetahui lebih banyak hal mengenai Islam. Tetapi masih terdapat sekitar 13\% mahasiswa yang membaca buku/bacaan keislaman karena beralasan mendapat tugas dari dosen maupun asisten. 

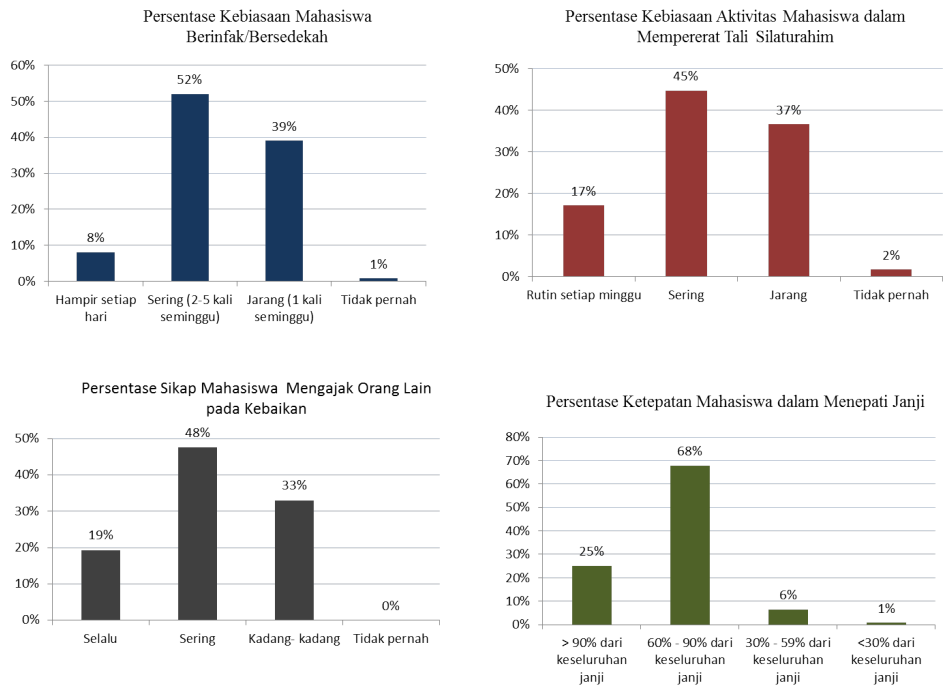

Gambar 4.8 Diagram Batang Kegiatan Muamalah Mahasiswa

Dari Gambar 4.8 dapat dilihat banyak mahasiswa yang sering melakukan kegiatan muamalah seperti berinfak, pergi bersilaturahim, mengingatkan orang lain pada kebaikan, dan menepati janji. Tapi masih terdapat sekitar 1\% - 2\% mahasiswa yang tidak pernah berinfak dan pergi bersilaturahim sama sekali. Selain itu juga terdapat $\pm 2 \%$ mahasiswa yang kurang amanah dengan janji yang dibuatnya.

Persentase Mengenai Peranan Keluarga dan Lingkungan terhadap Nilai-Nilai Keislaman Mahasiswa

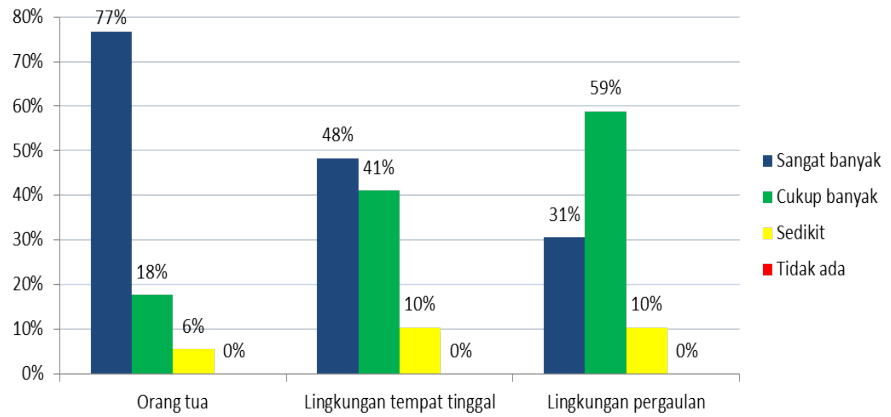

Gambar 4.9 Diagram Batang Mengenai Peranan Keluarga dan Lingkungan terhadap Nilai-Nilai Keislaman Mahasiswa

Dari gambar di atas dapat dilihat bahwa orang tua memiliki peranan yang paling besar terhadap penerapan nilai-nilai keislaman mahasiswa dibandingakan lingkungan tempat tinggal dan pergaulan. Sekitar $94 \%$ mahasiswa memiliki orang tua (keluarga) yang selalu/hampir selalu aktif dalam menjunjung dan menerapkan nilai-nilai keislaman dalam kehidupan sehari-hari.

\subsubsection{Pendapat dan Sikap Mahasiswa Mengenai Berbagai Aktifitas}

Mahasiswa memiliki pendapat atau pandangan tersendiri mengenai aktivitas yang terjadi di lingkungan sekitar mereka. Pandangan atau pendapat mahasiswa tersebut 
tidak selalu diikuti dengan perbuatan terhadap aktivitas yang mewakili pendapat mereka itu sendiri.

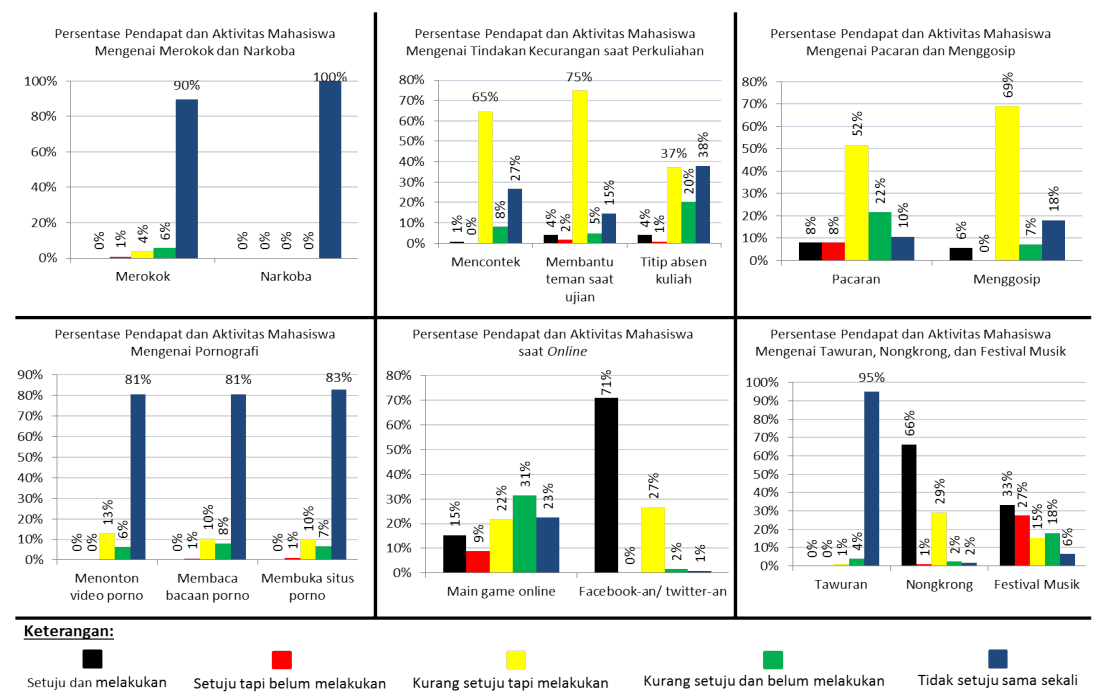

Gambar 4.10 Diagram Batang Pendapat dan Sikap Mahasiswa Mengenai Berbagai Aktifitas

Untuk aktivitas merokok, hanya terdapat 1\% mahasiswa yang menyetujui dan $4 \%$ mahasiswa yang melakukan kegiatan ini. Sedangkan untuk aktivitas mengenai narkoba, seluruh mahasiswa sama sekali tidak menyetujui kegiatan ini. Untuk perilaku kecurangan dalam perku-liahan seperti mencontek, membantu teman saat ujian, dan titip absen, ternyata banyak mahasiswa yang melakukan tindakan ini walaupun mereka mengakui kalau perbuatan tersebut tidak baik. Tidak jauh berbeda dengan perilaku kecurang-an saat kuliah, kegiatan pacaran dan menggosippun merupakan kegiatan yang banyak dilakukan mahasiswa walaupun mereka kurang menyetujui kegiatan tersebut.

Kegiatan menyimpang dalam hal pornografi sangat tidak disetujui oleh mahasiswa, tetapi masih terdapat sekitar 10\% mahasiswa yang tetap melakukannya walaupun kurang setuju. Untuk aktivitas bermain game online, terdapat $24 \%$ mahasiswa yang menyetujui kegiatan tersebut. Sedangkan untuk aktivitas online dengan media sosial cukup banyak yang menyetujuinya (sekitar 71\%). Aktivitas lainnya yang banyak tidak disetujui mahasiswa yaitu tawuran, sedangkan kegiatan nongkrong dan mengikuti festival musik masih banyak yang menyetujuinya.

\subsection{Uji Validitas dan Reliabilitas Intrumen Penelitian}

\subsubsection{Uji Validitas}

Dalam penelitian ini uji validitas dilakukan dengan metode Pearson, yaitu dengan mengkorelasikan skor butir pertanyaan pada kuisioner dengan skor variabel yang mewakili pertanyaan tersebut. Dengan bantuan program SPSS 16.0 for Windows, diperoleh nilai $r_{\text {hit }}$ untuk setiap pertanyaan lebih besar daripada nilai $r_{k r i t i k}$ (dengan taraf nyata 5\%), sehingga dapat disimpulkan bahwa masing-masing pertanyaan 
pada kuisioner valid untuk mengukur variabel yang diwakilinya.

\subsubsection{Uji Reliabilitas}

Berdasarkan hasil perhitungan, diperoleh indeks reliabilitas kuisioner adalah sebesar 0,8619. Indeks tersebut menunjukkan bahwa keterandalan kuisioner sangat tinggi dan dapat digunakan dalam penelitian ini.

\subsection{Analisis Gerombol dengan Metode K-Means}

Objek dibagi menjadi tiga gerombol, dimana masing-masing gerombol mewakili tingkat perilaku keagamaan mahasiswa dengan kriteria relatif lebih baik, cukup baik, dan kurang baik. Dengan bantuan program SPSS 16.0 for Windows, diperoleh hasil centroid masing-masing gerombol dan $F_{\text {rasio }}$ masing-masing variabel sebagai berikut:

Tabel 4.1: Cluster Centroid F rasio

\begin{tabular}{|l|c|c|c|c|}
\hline \multirow{2}{*}{\multicolumn{1}{|c|}{ Variabel }} & \multicolumn{3}{|c|}{ Centroid } & \multirow{2}{*}{ F rasio } \\
\cline { 2 - 4 } & Gerombol I & Gerombol II & Gerombol III & \\
\hline Shalat wajib & 21,40 & 20,24 & 16,13 & $\mathbf{3 6 , 5 1}$ \\
\hline Shalat sunnah & 10,20 & 8,92 & 7,04 & $\mathbf{2 5 , 8 8}$ \\
\hline Zikir/doa & 18,75 & 17,28 & 14,74 & $\mathbf{2 5 , 1 3}$ \\
\hline Puasa & 8,10 & 7,58 & 6,91 & $\mathbf{6 , 4 7}$ \\
\hline Alquran/Hadis & 11,65 & 8,97 & 7,65 & $\mathbf{3 7 , 2 2}$ \\
\hline Wawasan ilmu agama & 10,90 & 8,06 & 7,39 & $\mathbf{3 6 , 8 1}$ \\
\hline Muamalah & 13,55 & 11,27 & 10,48 & $\mathbf{2 1 , 6 3}$ \\
\hline Distribusi Objek & $\mathbf{1 6 , 5 3 \%}$ & $\mathbf{6 4 , 4 6 \%}$ & $\mathbf{1 9 , 0 1 \%}$ & \\
\hline
\end{tabular}

Dari Tabel 4.1 dapat dilihat bahwa nilai masing-masing variabel pada gerombol I lebih besar dibandingkan gerombol II dan gerombol III, sehingga dapat disimpulkan bahwa gerombol I memiliki tingkat perilaku keagamaan mahasiswa yang relatif lebih baik dibandingkan gerombol lainnya. Pada gerombol II, mahasiswa memiliki tingkat perilaku keagamaan yang relatif cukup baik, sedangkan gerombol III memiliki tingkat perilaku keagamaan mahasiswa yang relatif kurang baik. Selain itu distribusi mahasiswa yang paling banyak terletak pada gerombol II, sehingga dapat disimpulkan bahwa mayoritas mahasiswa jurusan Matematika angkatan 2013 memiliki tingkat perilaku keagamaan yang relatif cukup baik.

Dari tabel juga dapat dilihat bahwa setiap nilai $\mathrm{F}$ rasio $>\mathrm{F}$ tabel $=3,07$, sehingga dapat disimpulkan bahwa nilai tengah masing-masing gerombol tersebut tidak sama. Selain itu, nilai F tersebut dapat digunakan untuk mengetahui kepentingan dari setiap variabel dalam membedakan/mempengaruhi gerombol tersebut. Dari tabel tersebut dapat diketahui bahwa variabel yang paling mempengaruhi antar gerombol adalah Alquran/Hadis, wawasan ilmu agama, dan shalat wajib. Sedangkan variabel yang paling tidak mempengaruhi antar gerombol adalah pelaksanaan ibadah puasa.

\section{Penutup}

Dari uraian hasil deskriptif sebelumnya, dapat disimpulkan bahwa profil keagamaan mahasiswa tingkat 1 jurusan Matematika Universitas Andalas belum begitu 
baik, karena masih adanya mahasiswa yang tidak mengerjakan ibadah wajib secara rutin dan masih banyaknya mahasiswa yang tidak mengerjakan ibadah sunnah yang dianjurkan. Selain itu kepekaan atau minat mahasiswa dalam mencari ilmu dan informasi keagamaan masih kurang.

Berdasarkan hasil penggerombolan dengan metode $K$ - means diperoleh distribusi mahasiswa terbanyak terletak pada gerombol II, sehingga dapat disimpulkan bahwa mayoritas mahasiswa jurusan Matematika Universitas Andalas angkatan 2013 memiliki tingkat perilaku keagamaan yang relatif cukup baik.

\section{Ucapan Terima kasih}

Penulis mengucapkan terima kasih kepada Ibu Dr. Ferra Yanuar, Bapak Dr. Dodi Devianto, dan Bapak Dr. Mahdhivan Syafwan yang telah memberikan masukan dan saran sehingga paper ini dapat diselesaikan dengan baik.

\section{Daftar Pustaka}

[1] Afifi, A.A \& V. Clark. 1999. Computer-Aided Multivariate Analysis. Third Edition. Chapman \& Hall/CRC, New York

[2] Depdikbud. 1989. Kamus Besar Bahasa Indonesia. Balai Pustaka, Jakarta

[3] Guilford, S. P. \& B. Fruchter. 1973. Fundamental Statistics in Psichology and Education.Ed. ke-5. Mc. Graw Hill, New York

[4] Nasution, D.K. 2001. Profil Mahasiswa Muslim FMIPA IPB Berdasarkan Keaktifan dalam Kegiatan Keislaman. Skripsi $S$-1, tidak diterbitkan

[5] Singarimbun, M. \& S. Effendi (editor). 1989. Metode Penelitian Survei, edisi revisi. LP3S, Jakarta

[6] Sugiyono. 2006. Statistika Untuk Penelitian. CV Alfabeta, Bandung

[7] Walpole, R.E. 2007. Pengantar Statistika. Ed ke-3. Terjemahan Bambang Sumantri. Gramedia Pustaka Umum, Jakarta 